\title{
IAMJ
}

INTERNATIONAL

AYURVEDIC

MEDICAL JOURNAL

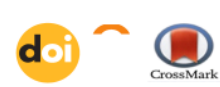

Research Article

ISSN: 2320-5091

Impact Factor: 6.719

\section{CLINICAL STUDIES ON MILD POST COVID SYNDROME WITH IWALL TABLET}

\section{Naringe Yogendra Seema}

Professor in Swasthavritta, Shri Ayurved Mahavidyalaya, Nagpur - Maharashtra, India

Corresponding Author: naringeseema@gmail.com

1https://doi.org/10.46607/iamj09p5022021

(Published online: January 2020)

Open Access

(C) International Ayurvedic Medical Journal, India 2021

Article Received: 08/02/2021 - Peer Reviewed: 09/02/2021 - Accepted for Publication: 11/02/2021

Check for updates

\section{ABSTRACT}

COVID-19 Cases across the globe is more than 100 million. Subsets of people who have recovered from COVID-19 experience symptoms that remain even after testing negative for the virus, these set of symptoms are called Post COVID Syndrome or long COVID. Researchers all over the world are trying to deal with this disease. Ayurveda will be of great help for the entire world in dealing with this Syndrome so present study was carried out with iWALL tablet which is a polyherbal Ayurvedic formulation to see the efficacy and safety of this drug in Mild Post COVID Syndrome. In this study 25 patients with Mild Post COVID Syndrome like fatigue, myalgia, cough, sore throat and shortness of breath were treated with iWALL Tablet $750 \mathrm{mg}$ two times a day for 3 month. All the data collected statistically shows significant results and study concluded that iWALL tablet is effective and safe in Mild Post COVID Syndrome.

Keywords: Post COVID -19 Syndrome, Long COVID, Post COVID Management, iWALL Tablet.

\section{INTRODUCTION}

COVID-19 is a relatively new disease caused by SARS COV-2 Virus. A recent US study shows that only $65 \%$ people had returned to their previous level of health 14 to 21 days after a COVID-19 positive test. ${ }^{1}$ Many research studies shows that approximately $10 \%$ of the population which shows Post COVID Syndrome recovered spontaneously with Holistic support, rest, symptomatic treatment and gradual increase in activity. $^{2}$ Not only Hospitalized severe COVID-19 patients but also non hospitalized mild COVID-19. ${ }^{3}$ Patients which were physically fit before onset of symptoms also shows Post COVID-19 symptoms. ${ }^{4}$ There is no clear picture what constitutes Post COVID Syndrome and it is difficult to assess how common it is, how long it lasts, who is at risk 
for it, what are the causes, pathophysiology, prevention and treatment. ${ }^{5}$ The reason for Post COVID Syndrome is may be role of SARS COV-2 virus in functioning of the body by continue to linger in body and destabilizes the Immune response. ${ }^{6}$ These persistent symptoms pose new challenges to health care providers. Ayurveda by virtue of its holistic approach towards health and disease and cost effectiveness have an edge in dealing with health problems including recent Post COVD Syndrome. Post COVID management protocol released by government of India ministry of health includes Ayush Quath, Samshamanini vati, Ashwagandha churna, Chayawanprash etc. ${ }^{7}$ Many Ayurvedic research study shows results of Ayurvedic drugs in COVID-19 but very few studies were there on results of Ayurvedic formulations on Post Covid-19 Syndrome so present study is carried out to see the efficacy of Ayurvedic polyherbal formulation iWALL Tablet on Post COVID 19 Syndrome.

Aims and Objective of the study: To assess the efficacy and safety of the iWALL Tablet in Mild Post COVID Syndrome.

\section{Materials and methods:}

In this clinical study non hospitalized 25 mild COVID-19 positive patients who showed Mild Post COVID-19 symptoms like fatigue, myalgia, cough, sore throat and shortness of breath were included in study. All these patients were clinically examined weekly for temperature, heart rate, blood pressure SPO2 etc. and information recorded on clinical profarma. Written informed consent was taken from the patient. Patients were advised to check oxygen saturation daily.

Level of the study-OPD

Schedule of the drug: These patients were treated with iWALL Tablet $750 \mathrm{mg}$ two times a day for 3 months after meals with water.
Duration of the study: 12 weeks.

Sample size: 25

Number of Groups: Single.

Selection of the patients: Patients were randomly selected using Random sample Method.

iWALL Tablet is a research-based poly herbal Ayurvedic formulations- manufactured at Zoetic Ayurvedic GMP certified plant. It contains 9 different Ayurvedic herbs like Guduchi $75 \mathrm{mg}$, Gokshura $100 \mathrm{mg}$, Amalaki $100 \mathrm{mg}$, Ashwagandha150mg. Shatavari $150 \mathrm{mg}$, Maricha $75 \mathrm{mg}$, Haridra $75 \mathrm{mg}$, Twaka $50 \mathrm{mg}$, Lawanga $50 \mathrm{mg}$.

Inclusion Criteria: 1) Patients who were non hospitalized and were Reverse transcriptase polymerase chain reaction (RT-PCR) Positive and after recovery from illness shows Mild Post COVID-19 symptoms like fatigue, myalgia, cough, sore throat and shortness of breath after 1 month from onset of symptoms of COVID-19 were included in study.

2) Patients between 25 to 50 years of age.

3) Patients with SPo2 96 or more were included in study.

Exclusion Criteria: Patients who have a history of chronic respiratory, cardiovascular or neurological disorders.

2) Patients who received noninvasive or invasive oxygen supply.

3) Patients with any co-morbidities like Diabetes and Hypertension.

Subjective Criteria: Patients with following symptoms post recovery from COVID- $19^{8}$

1) Fatigue, 2) myalgia, 3) cough, 4) sore throat, 5) shortness of breath were included in study.

Assessment Criteria: All the symptoms were critically analyzed and rated as per scoring pattern of mild, moderate and severe symptoms as follows

\section{Table 1:}

\begin{tabular}{|l|l|l|}
\hline Symptom & Severity & Score \\
\hline \multirow{5}{*}{ Fatigue } & 1) Fatigue without exertion & 4 \\
\hline & 2)Fatigue with exertion & 3 \\
\hline & 3)Fatigue disturbing daily routine & 2 \\
\hline & 4)Fatigue not disturbing daily routine & 1 \\
\hline & 5)No Fatigue & 0 \\
\hline Myalgia & 1)Muscle pain is throughout day restricting daily routine & 4 \\
\hline & 2)Muscle pain intermittently disturbing daily routine- & 3 \\
\hline & 3)Muscle pain intermittently not disturbing daily routine- & 2 \\
\hline & 4)Muscle pain occasionally not disturbing daily routine- & 1 \\
\hline & 5)No Muscle pain & 0 \\
\hline \multirow{5}{*}{ Cough $^{8}$} & 1)Severe strenuous cough accompanied by chest discomfort most of the times in a day & 4 \\
\hline & 2)Moderate paroxysmal cough intermittently & 3 \\
\hline & 3)Mild isolated cough occasionally & 2 \\
\hline
\end{tabular}




\begin{tabular}{|l|l|l|}
\hline \multirow{5}{*}{ Sore throat } & 4)Occasional hems & 1 \\
\hline 5)No cough & 0 \\
\hline & 1)Severe inflammation of throat with fever and difficulty in swallowing & 4 \\
\hline & 2)Moderate inflammation of throat with no fever and difficulty in swallowing & 3 \\
\hline & 3)Mild inflammation with no fever and occasional difficulty in swallowing & 2 \\
\hline & 4)Mild inflammation with no fever and no difficulty in swallowing & 1 \\
\hline 5)No inflammation & 0 \\
\hline Shortness of Breath & 1)Breathless without exertion & 4 \\
\hline & 2)Breathless after exertion & 3 \\
\hline & 3)Breathless not affecting daily routine & 2 \\
\hline & 4)Breathless noticeable to patient not to observer & 1 \\
\hline & 5)No Breathless & 0 \\
\hline
\end{tabular}

Statistical analysis was done using SD, SE calculated on the basis of scoring pattern of symptoms before and after treatment.

Assessment of results: Assessment was made weekly and results were analyzed before and after treatment and divided in following four groups

1) Good Response: Patients with more than $75 \%$ improvement in symptoms were included in this group.

2) Fair Response: Patients with more than $50 \%$ to $75 \%$ improvement in symptoms were included in this group.

3) Poor Response: Patients with more than 25 to $50 \%$ improvement in symptoms were included in this group.

4) No Response: Patients with less than $25 \%$ improvement in symptoms were included in this group.

Observation and Results: The data collected were distributed according to age sex, income, occupation etc.

1. Incidences of Mild Post COVID Syndrome is more in the 40 to 50 -year age group (44\%) followed by 30 to 40 age group.
2. Incidence of this disease is more in females $(60 \%)$ than male $(40 \%)$

3. Middle income group patients are more prone to Mild Post COVID Syndrome (44\%) followed by higher income group (32\%).

4. Occupation wise distribution shows that businesspersons are more affected with this disease (44\%) followed by service persons (32\%)

5. Kaphaj and Pittaj Prakruti patients show an equal incidence of this disease that is $36 \%$.

6. iWALL Tablet is highly effective in reducing almost all Mild Post COVID Syndrome.

7. iWALL Tablet is comparatively more effective in reducing symptoms like Fatigue and Sore throat.

8. iWALL Tablet is safe in Mild Post COVID Syndrome. Assessment of Results shows that iWALL Tablet shows Good Response in 48\% patients and Fair Response in 32\% patients and Poor Response in $20 \%$ patients and no patients show nil response.

Graph 1: Showing age wise classification of 25 patients of Mild Post COVID Syndrome.

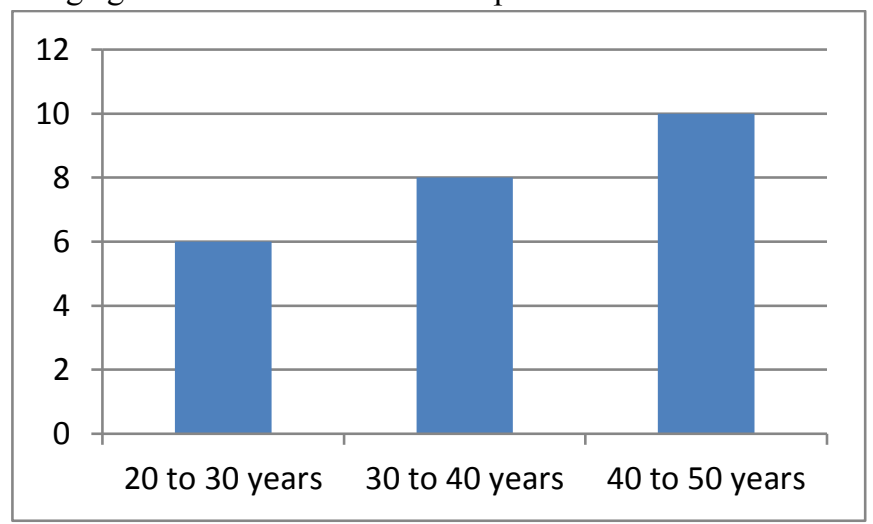

Above observation shows that as per age wise classification $44 \%$ patients were found in the 40 to 50 age group followed by $32 \%$ in the 30 to 40 years age group. 
Graph 2: Showing income wise classification of 25 patients of Mild Post COVID Syndrome

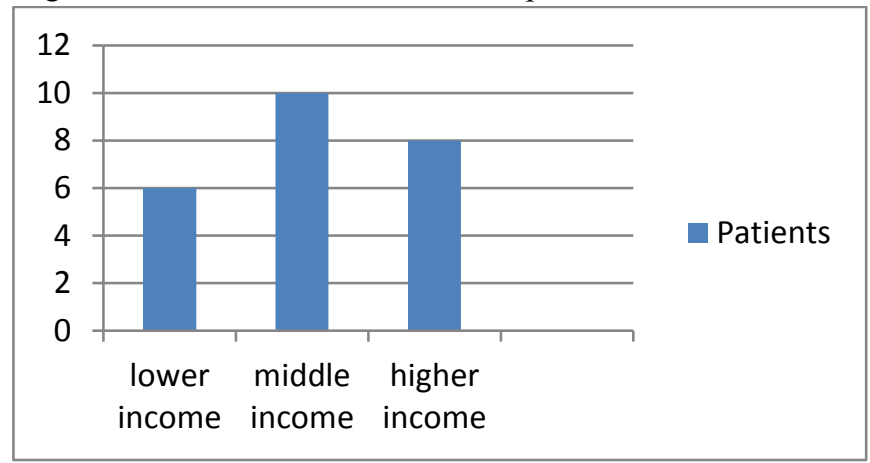

Above observation shows that as per income wise classification $44 \%$ patients were found in the middle-income group followed by $32 \%$ in the higher income group.

Graph 3: Prakruti wise classification of 25 patients of Mild Post COVID Syndrome

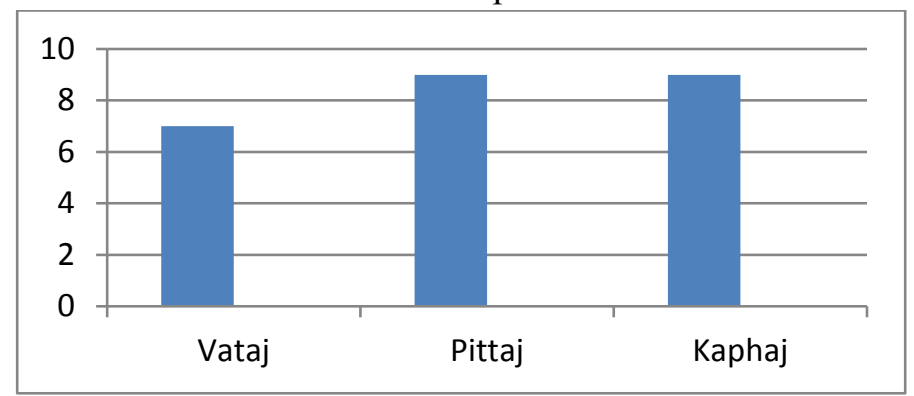

Above observation shows that as per Prakruti wise classification 36\% patients were found in Pittaj and Kaphaj group followed by $28 \%$ in Vataj age group.

Table 2: Statistical Analysis of effect of iWALL Tablet on Subjective parameters in Mild Post COVID-19 Syndrome

\begin{tabular}{|l|l|l|l|l|l|l|}
\hline Symptom & Mean & S.D & S.E & Median & $\begin{array}{l}\text { Confidence interval at 99\% } \\
\text { confidence }\end{array}$ & $\begin{array}{l}\text { 't' score at 0.01 level of } \\
\text { significance }\end{array}$ \\
\hline Fatigue BT & 3.28 & 0.89 & 0.18 & 4 & 0.46 & 103.520 \\
\hline Fatigue AT & 0.36 & 0.57 & 0.11 & 0 & 0.29 & 66.828 \\
\hline Myalgia BT & 3.44 & 0.65 & 0.13 & 4 & 0.34 & 99.536 \\
\hline Myalgia AT & 0.64 & 0.57 & 0.11 & 1 & 0.29 & 69.628 \\
\hline Cough BT & 2.84 & 0.62 & 0.12 & 3 & 0.32 & 92.928 \\
\hline Cough AT & 0.32 & 0.48 & 0.10 & 0 & 0.25 & 64.275 \\
\hline Sore Throat BT & 2.84 & 0.47 & 0.09 & 3 & 0.24 & 89.393 \\
\hline Sore Throat AT & 0.02 & 0.41 & 0.08 & 0 & 0.21 & 61.497 \\
\hline Shortness of Breath BT & 3.16 & 0.47 & 0.09 & 3 & 0.24 & 92.593 \\
\hline Shortness of Breath AT & 0.32 & 0.48 & 0.10 & 0 & 0.25 & 64.275 \\
\hline
\end{tabular}

The above data shows drastic decrease in the means of all symptoms. Further, through the statistical analysis at 0.01 significanse level and 24 degrees of freedom, we know that ' $t$ ' values before and after treatment have reduced across all symptoms shows that i WALL Tablet is effective in reducing all subjective parameters. 
Table 3: Assessment of results

\begin{tabular}{|l|l|l|}
\hline Type of Response & Number of patients & Percentage \\
\hline Good Response & 12 & $48 \%$ \\
\hline Fair Response & 08 & $32 \%$ \\
\hline Poor Response & 05 & $20 \%$ \\
\hline No Response & 00 & 00 \\
\hline
\end{tabular}

Graph 4:

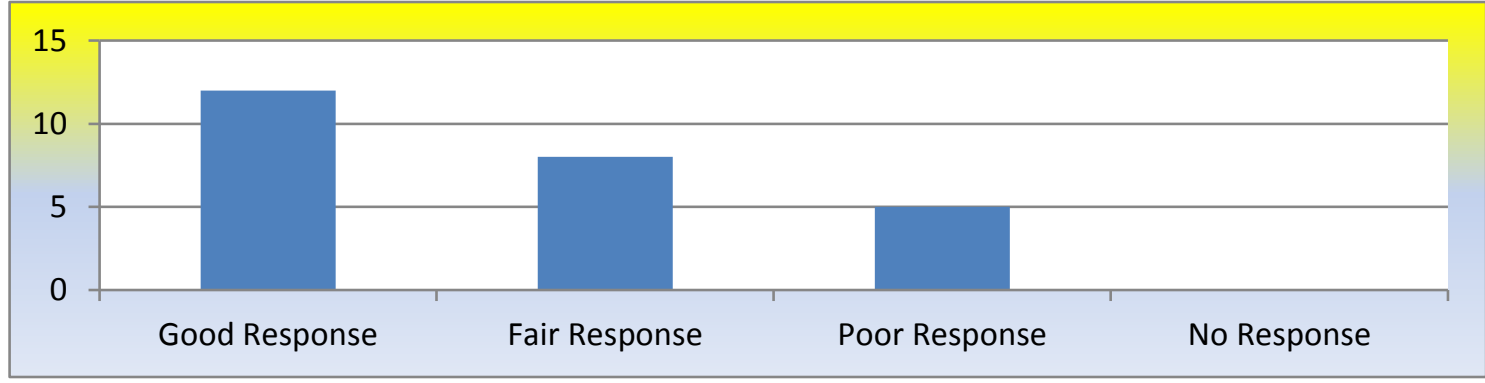

After Complete course of treatment good response was observed in 12 patients $(48 \%)$ and 8 patients shows fair response that is (32\%), 4 patients (20\%) shows poor response but no patient shows nil response so we can say that iWALL Tablet is highly effective in Mild Post COVID Syndrome.

\section{DISCUSSION}

Ayurveda has been included in the national treatment protocol for COVID-19 and post COVID management jointly launched by Ministry of health and family welfare and ministry of AYUSH. ${ }^{9}$ This protocol includes immunity boosting drugs like Ashwagandga, Guduchi, chyawanprasha and anti-viral anti-bacterial drug like Krushna Maricha, Haridra, Twaka, Lawanga etc. ${ }^{\mathbf{1 0}}$ Though it is not cleared why patients suffered with Post COVID-19 Syndrome however boosting immunity and use of antiviral and antibacterial herbal drugs help in recovery. It is well known that immunity modulators help in complete recovery from disease. iWALL Tablet is a combination of immunity booster drug and drug with anti-viral and bacterial properties which can be summarized in the following table.

Table 4: Ingredients of iWALL Tablet and its properties

\begin{tabular}{|l|l|}
\hline Ingredients & Probable mode of action \\
\hline $\begin{array}{l}\text { Guduchi } \\
\text { (Tinospora } \\
\text { cordifolia) }\end{array}$ & $\begin{array}{l}\text { Guduchi have Rasayana and Tridoshashamak properties and highly effective as immunomodulator and } \\
\text { enhance the bodies fighting mechanism against bacteria and virus }{ }^{11} \text { and thus play role in relieving all } \\
\text { the symptoms of post COVID Syndrome fatigue, Myalgia, cough, sore throat and shortness of breath. }\end{array}$ \\
\hline $\begin{array}{l}\text { Gokshura (fruit) } \\
\text { Tribulus } \\
\text { Terrstaris) }\end{array}$ & $\begin{array}{l}\text { Saponins from fruit of Gokshura are known to increase phagocytosis and hence it is highly effective in } \\
\text { increasing immune response }{ }^{12} \text { of the body and help in relieving symptoms like fatigue and due to its } \\
\text { analgesic properties useful in myalgia and due to its anti-inflammatory and antibacterial properties } \\
\text { useful in symptoms like cough, sore throat shortness of breath. }\end{array}$ \\
\hline $\begin{array}{l}\text { Amalaki (fruit) } \\
\text { (Embelica } \\
\text { officinalis) }\end{array}$ & $\begin{array}{l}\text { Amalaki is a Rasayana drug and have powerful antioxidant properties contains vitamin C and is shown } \\
\text { to protect the body from harmful effects of free radicals }{ }^{13} \\
\text { And relieves all the symptoms of Post COVID Syndrome. }\end{array}$ \\
\hline $\begin{array}{l}\text { Ashwagandha } \\
\text { (Witania } \\
\text { Somnifera) }\end{array}$ & $\begin{array}{l}\text { It is Rsayana drug n is proven immune booster drug which works as anti-inflammatory agent }{ }^{14} \text { and acts } \\
\text { as adaptogen, reduces stress and is useful in all Mild Post COVID Syndrome. }\end{array}$ \\
\hline $\begin{array}{l}\text { Shatavari } \\
\text { (Asparagus } \\
\text { Recemosus) }\end{array}$ & $\begin{array}{l}\text { Shatavari is excellent Rasayana and known to have immunomodulatory and immunoadjuvant action } \\
\text { 15,16 and thus helpful in relieving Fatigue, Myalgia, cough, sore throat and shortness of breath. }\end{array}$ \\
\hline Maricha (Piper & Maricha contains Peppercorn and Piperine which exhibits immunomodulatory and antibacterial \\
\hline
\end{tabular}




\begin{tabular}{|l|l|}
\hline Nigrum) & $\begin{array}{l}\text { properties and due to Yogwahi property which enhances properties of supplementary drug used help in } \\
\text { bioavailability of other herbal combination in the body }{ }^{17} \text { and special useful in symptoms like cough, } \\
\text { sore throat and shortness of breath. }\end{array}$ \\
\hline $\begin{array}{l}\text { Haridra } \\
\text { (Curcuma Longa) }\end{array}$ & $\begin{array}{l}\text { This drug not only reduces inflammation in the body but also helps to reduce viral replication in the } \\
\text { body }^{18} \text { and is useful in relieving symptoms like Myalgia, cough, sore throat and shortness of breath. }\end{array}$ \\
\hline $\begin{array}{l}\text { Twaka (Dalchini) } \\
\text { Cinnamonum } \\
\text { Zeylancium) }\end{array}$ & $\begin{array}{l}\text { It is a potent antioxidant, antimicrobial, antifungal and antiviral agent }{ }^{19} \text { and useful to relieve symptoms } \\
\text { like cough, sore throat and shortness of breath. }\end{array}$ \\
\hline $\begin{array}{l}\text { Lawanga } \\
\text { (Clove) } \\
\begin{array}{l}\text { Syzygium } \\
\text { aromaticum }\end{array}\end{array}$ & $\begin{array}{l}\text { It is a natural antioxidant having antibacterial and antiviral properties }{ }^{20} \text { also cloves have great oxygen } \\
\text { radical absorbance capacity }{ }^{21} \text { and mainly useful in relieving symptoms like cough, sore throat and } \\
\text { shortness of breath. }\end{array}$ \\
\hline
\end{tabular}

From above table it is clear that iWALL Tablet contains Rasayana drug like Guduchi Gokshur Amalki, Ashwagandha and Shatavari which contains phytochemicals which possibly restores pulmonary health by strengthening endothelial dysfunction and reduce oxidative stress. $^{22}$ that's why it is useful in Post COVID Syndrome where Respiratory system is mainly involved. Immunomodulation actions of Rasayana promotes health by promoting strength to strotas, boosting digestive power, strengthening physique and act as rejuvenator in a disease person and thus helps in mainly in Fatigue and Myalgia Along with cough, sore throat and shortness of breath ${ }^{23}$. Remaining ingredients of iWALL Tablet Maricha, Haridra, Twaka, Lawanga possess antioxidant, antibacterial and antiviral properties which are helpful in relieving symptoms like cough, sore throat and shortness of breath. Along with this as iWALL Tablets are uncoated which helps in faster absorption of the drug. This drug during the complete course of treatment does not show any adverse effect in patients. From the above discussion we can say that iWALL Tablet is highly effective in Mild Post COVID Syndrome by virtue of its Rsayana and antioxidant, antibacterial and antiviral properties.

\section{CONCLUSION}

From the above study it can be concluded that the iWALL Tablet shows statistically significant results in Mild Post COVID-19 Syndrome and iWALL Tablet is safe and effective in Mild Post COVID Syndrome.

\section{REFERENCES}

1. Tenforde MW, Kin SS et al, IVY network investigators, CDC COVID 19 response team. Symptoms, duration and risk factors for delayed return to usual health among outpatients with COVID 19 in a multitask healthcare systems network-United States March -June 2020.MMWR Morb Mortal wkly Rep 202;69;993-

8.https.//www.cdc.gov/mmwr/volumes/69/wr/mm6930 el.htm.

2. Gemelli against COVID-19 Post-Acute Care study group. Post COVID-19 global health strategies; the need for an interdisciplinary approach. Aging Clin Exp Res2020;DOI:10.1007/s40520-020-01616x.pmid:32529595.

3. Callord F. Very, very mild COVID-19 symptoms and illness classifications. Somastosphere 2020; HTTP.//Somatosphere.net/2020/mild-Covid.html/.

4. Asthma UK and British Lung foundation. Get support after COVID-19. Post COVID HUB 2020. https :wwwpost-covid.org.UK/get support/.

5. Matthew E Levision. Commentary what we know so far about Post COVID Syndrome.9/24/2020.www.msdmanuals.com. Assesed date $24 / 01 / 2021$.

6. Timesofindia.imdiatimes.com > long covid: who has the higher risk of developing covid.22.october/2020.assesed date 21/01/2021

7. www.mohfw.gov.in $>$ pdf $>$ post covid management protocol.13 ${ }^{\text {th }}$ September 2020.Assesed date 20/01/2021.

8. Fisher man et al. The combine cough frequency and severtiy scoring a new approach to cough evaluation in clinical settings. J. Med. 2001.

Pubmed.ncbi.nlm.nih.gov>

9. Anjelo Carfi et. al. Persistent symptoms in Patients after acute COVID-19. JAMA 2020;324(6):603605.doi:10.1001/jama2020.12603. 
10. www.hindustantimes.com.>Ayurveda,Yoga to deal with post COVID-19 problems: Shripad Naik.22/nov.2020, assessed date 1/02/2021.

11. www.mohfw.gov.in $>$ pdf $>$ post covid management protocol.13 ${ }^{\text {th }}$ September 2020.Assesed date 20/01/2021.

12. Saha, Soham and Shyamashri ghosh." Tinospora Cordifolia: one olant many roles' ' Ancient science of life.vol.314(2012): 151-9.doi:10.4103/02577941.107344.

13. Chhatre Saurabh et al. Phytopharmacological properties of Tribulus Terrestaris". Pharmacognosy reviews.vol.8,15(2014): 45-51.doi:10.4103/09737847.125530

14. Singh, Manish Ket al. Immunomodulatory role of Embelica officinalis in Arsenic induced oxidative damage and apoptosis in thymocytes of mice." BMC Complementary and Alternative Medicine. Vol.13,193(2013). doi:10.1186/1472-6882-13-193.

15. M. Gupta et al. Immunomodulatory activity of tha Ayurvedic formulation Ashwagandha churna", Pharmaceutical Biology. (2006); 44:4,263-65, doi:10.1080/13880200600713949.

16. Alok,Dr.Shasti et al.Plant profile,phytochemistry and pharmacology of Asparagus Racemosus (Shatavari):A review. Asian Pacific J. of Tropical Disease.3.24252.doi:10-1016/s2222-1808(13)60049-3.

17. N Hasan, et al. Asparagus racemosus: For medicinal uses and pharmacological actions. Int. J of Adv. Res 4(Mar 2016). 259-67.

18. Kesarwani, Kritika et al. "Bioavailability enhancers of herbal origin: an overview." Asian Pacific Journal of tropical biomedicine vol. 3,4(2013): 253-66. Doi :10.1016/S2221-1691(13) 60060-X.

19. Chattopadhaya, Ishita, et al. Turmeric and curcumin: Biological actions and medical applications".

Current science bangalore-87(2004):44-53.

20. Gruenwald, Joerg, et al. "Cinnamon and Health". Critical review in food science and nutrition 50.9(2010):822-34.

21. Cortes-Rojas, et al." Clove (Syzygium aromaticum): a precious spice". Asian Pacific Journal of tropical biomedicine vol. 4, 2 (2014): 90-6. Doi :10.1016/S2221-1691(14) 60215-X.

22. K Beniayeb et al. The additive properties of oxygen radical absorbance capacity. Food chemistry volume 148 (2014): 204-08.

23. Kush et al. Rasayana drugs promise better antcovid -19 medication. Asian J Pharm Res. Dec 202020;8:148-9
24. Nagendra H R. Yoga for COVID-19. Int. J. Yoga 2020;13:87/8.

\section{Source of Support: Nil \\ Conflict of Interest: None Declared}

How to cite this URL: Naringe Yogendra Seema: Clinical Studies On Mild Post Covid Syndrome With I-Wall Tablet. International Ayurvedic Medical Journal \{online\} 2021 \{cited January, 2021\} Available from: http://www.iamj.in/posts/images/upload/2714 2720.pdf 